\title{
LUT
}

University

\section{Transnational Entrepreneurial Ecosystems: The Perspectives of Finnish and Estonian Born-Global Start-Ups}

\author{
Velt Hannes, Torkkeli Lasse, Saarenketo Sami
}

This is a Author's accepted manuscript (AAM) version of a publication

published by Edward Elgar Publishing Limited

in Research Handbook on Start-Up Incubation Ecosystems

DOI: $10.4337 / 9781788973533$

Copyright of the original publication: () Novotny, Rasmussen, Clausen and Wiklund 2020

Please cite the publication as follows:

Velt, H., Torkkeli, L., Saarenketo, S. (2020). Transnational Entrepreneurial Ecosystems: The Perspectives of Finnish and Estonian Born-Global Start-Ups. Research Handbook on Start-Up Incubation Ecosystems, pp. 110-134. Edward Elgar Publishing Limited. DOI:

$10.4337 / 9781788973533$

This is a draft chapter. The final version is available in Research Handbook on Start-Up Incubation Ecosystems edited by Novotny et. al., published in 2020, Edward Elgar Publishing Ltd. http://dx.doi.org/10.4337/9781788973533 The material cannot be used for any other purpose without further permission of the publisher, and is for private use only.

This is a parallel published version of an original publication. This version can differ from the original published article. 


\title{
Transnational Entrepreneurial Ecosystems: The Perspectives of Finnish and Estonian Born-Global Start-Ups
}

\begin{abstract}
The entrepreneurial-ecosystem concept has recently gained renewed attention among entrepreneurship scholars, yet research in the fields of regional studies and international entrepreneurship has stayed notably silent on the role that incubating environments can have in driving entrepreneurial activities in developing rapidly internationalising born-global (BG) firms.

In this exploratory study, we seek to further the discussion on the role that the entrepreneurial ecosystem can have in the research on international entrepreneurship affecting firm development. We assess entrepreneurial ecosystems in Finland and Estonia from the point of view of BG entrepreneurs and do so in a transnational-ecosystem context. Using a survey method and data analysis employing an analysis of variance (ANOVA), this study contributes to the literature on regional studies and international entrepreneurship by examining which of the transnational entrepreneurial ecosystem's structural elements are critical for start-ups during their developmental stages and how these elements are perceived differently depending on the characteristics of BG firms. The study thus enhances understanding of the interactions of the transnational entrepreneurial ecosystem and its role in supporting new ventures.
\end{abstract}

Keywords: transnational entrepreneurial ecosystem, born-global start-ups, financial capital, knowledge, networks, Finland, Estonia.

JEL subject code: F60, L25, L26, M13, O52 


\section{INTRODUCTION}

The entrepreneurial-ecosystem concept has gained much attention from scholars in diverse research disciplines during recent years (Maroufkhani et al., 2018); it is, however, still a young stream of research and lacks coherent insights required to expose how the ecosystem influences entrepreneurial activities and thus the consequent value creation. In previous decades, studies have focused on the established concepts of industrial districts, clusters and innovation systems to describe unique entrepreneurial environments (Autio et al., 2018). Yet, newer studies focusing on the co-creation of the setting and the aspirations of local entrepreneurs (Spigel and Harrison, 2018) have gained their place at the heart of international business and entrepreneurship studies. All the recent advancements in ecosystem contextualisation have been constructive, however, Mack and Mayer (2016) argue that previous efforts to identify entrepreneurial ecosystems are still too narrow and are based on already well-performing communities, and that they should be updated to create the grounds for additional investigations focusing on the entrepreneurial entities.

Moreover, consensus on what constitutes a successful ecosystem has not yet been reached, thus there is a need to produce studies to better capture the phenomenon in full. For example, how are entrepreneurial environments constructed (Kshetri, 2014) and how do they promote entrepreneurially-driven firms during rapid progress towards global markets (Ács et al., 2016)? In addition, the advancement of new theoretical frameworks and views on the ecosystem construct would allow us to challenge the status quo and gain insights into the conditions supporting firm growth and international expansion across regional geographies (Zander et al., 2015). Hence, following venture creation in the regional entrepreneurial context (Ács et al., 2017; Borissenko and Boschma, 2017; Cavusgil and Knight, 2015) would help us to elaborate the structural conditions (Stam, 2014) facilitating the risk-taking actions of entrepreneurs in finding opportunities to globally enhance societal value propositions.

Subsequently, to explore the entrepreneurial-ecosystem context, it is essential to understand the prerequisites affecting the entrepreneurial activities in developing globally-scalable firms. Thus, exploring the ecosystem's structural elements through the views of the founders becomes the focal point. In other words, studying how rapidly internationalising firms develop in the entrepreneurial ecosystem and which elements are critical in supporting high-risk-high-reward 
activities (Cavallo et al., 2018) would explain the uniqueness of the regional entrepreneurial ecosystems and how are they perceived by the entities operating in them. Therefore, the context becomes relevant and an appropriate setting should be chosen for further exploration.

Traditionally, international growth-oriented firms that have a strong capability towards creating an innovation-driven environment (Cannone and Ughetto, 2014) are common in countries with small domestic markets (Luostarinen and Gabrielsson, 2006). However, as smallness often refers to deficiencies, entrepreneurial ecosystems tend to share and compete for the same resources (e.g., human capital). Fortunately, unlike many regions in the world, in the European Union, the free movement of labour is part of the four economic freedoms (European Union, 2012). This is a strong enabler for small countries to compete over and acquire appropriate resources. In the light of this transformative process, there is potential for transnational entrepreneurship (Bailetti, 2018; Lundberg and Rehnfors, 2018). As small ecosystems are bound to share resources, they may perhaps converge certain goals and policies, and create a transnational entrepreneurial ecosystem on the regional level.

Considering the above, countries such as Finland and Estonia would be good case examples, as both are small economies while being start-up-intensive and familiar with nurturing "unicorn" (i.e., start-ups valued at over 1 billion dollars) born-globals (BGs; e.g., Rovio, Supercell, Skype and TransferWise). Finland and Estonia could be considered a transnational region with a substantial human resource concentration in their capital regions (Sergeevich and Alekseevna, 2015), making these countries share and complement their sources of goods, services, labour and capital. This, in turn, enables them to collaborate and create economic synergies (Nauwelaers et al., 2013) and form the antecedents for the integration of regional skills and capabilities. Hence, it is relevant to look at these entrepreneurial ecosystems from the transnational viewpoint (Velt et al., 2018a) to determine what makes these converging environments unique from the vantage point of local entrepreneurs and how they support the internationalisation of highgrowth firms.

In sum, there is a need for further exploration regarding how transnational entrepreneurial ecosystems and their structural elements influence BG start-up development and how the specific characteristics of a firm impact the perceptions of the regional ecosystem. Thus, the present study aims to address how an incubating ecosystem augments and encourages BG start-ups' 
development and internationalisation by seeking answers to two research questions (RQs) in particular:

RQ1. Which elements of the transnational ecosystem are critical for BG progress during the early stages?

RQ2. How do BG perceptions differ depending on the intra-group characteristics?

The remainder of the study is structured as follows: In the next section, we review key concepts and outline the research methodology, after which the results are then presented. In the last section, we discuss our findings with respect to the RQs and conclude with the theoretical and managerial implications, limitations of the study and avenues for future research.

\section{ENTREPRENEURIAL ECOSYSTEMS AND BORN-GLOBALS}

The concept of an entrepreneurial ecosystem was proposed late in the last century (Bahrami and Evans, 1995; Moore, 1993; Spilling, 1996; Van de Ven, 1993) as more reputable concepts (e.g. clusters and networks) were found to have limitations for elaborating the role of the entrepreneur in the local economic context (O'Connor et al., 2018). Hence, in recent years, the entrepreneurial ecosystem has gained renewed attention (Ács et al., 2018; Autio et al., 2018; O'Connor et al., 2018; Spigel and Harrison, 2018) to comprehend how the local environment nurtures the entrepreneurial lifeforce. Thus, the entrepreneurial ecosystem has been defined as "a combination of social, political, economic and cultural elements within a region that support the development and growth of innovative start-ups and encourage nascent entrepreneurs and other actors to take the risks of starting, funding and otherwise assisting high-risk ventures" (Spigel, 2017, p. 50). Based on Stam's (2015) belief regarding the surrounding ecosystem, there are two sets of conditions relevant for nurturing entrepreneurial activities on the framework and systemic levels. In his view, the systemic elements directly influence entrepreneurial activities during the development of BG firms. Henceforth, we use Velt et al.'s (2018b) view of the systemic elements and sub-elements to elaborate the local context. However, as we have proposed a two-country context where both systems are sharing resources across a border, we introduce a "transnational" dimension to the context and refer to it as a transnational entrepreneurial ecosystem. 
Moreover, entrepreneurial activities, domestic or international, are processes that encompass "the discovery, evaluation and exploitation of opportunities for creating future goods and services" (Shane and Venkataraman, 2000, p. 218), however, these processes commence on home ground. Hence, local conditions are relevant for capturing the creation of value and nurturing the needs of new ventures under conditions of resource scarcity (Sasi and Arenius, 2012) and rapid progress (Nummela et al., 2016). In addition, constant attention is placed on growth-oriented ventures in the current literature on entrepreneurial ecosystems (Alvedalen and Boschma, 2017; Mason and Brown, 2014). Thus, focusing on BG firms (Knight and Cavusgil, 2005; Oviatt and McDougall, 1994) in the entrepreneurial-ecosystem context is a suitable approach to take as BGs create value "through the identification and exploitation of opportunities that cross national borders" (Peiris et al., 2012, p. 296). However, to shed light on the dynamic relationships and aspects of the ecosystem influencing BGs, it is important to concentrate on the criticality of the elements and how they affect the processes in each of the firm's life-cycle stages. Thus, we chose the Marmer Stages (Marmer et al., 2011) that have been widely used by practitioners in start-up communities. Therefore, we focus on the first stages of discovery and validation, arguably because the regional ecosystem has its strongest influence on BGs as they are still homebound while being launched and supported with the aim of starting rapid internationalisation. Broadly put, the discovery stage includes entrepreneurial processes involved in forming and launching new BG start-ups, and the validation stage includes the authentication activities of the offer and visible expansion into foreign markets.

Subsequently, by incorporating all sides of the framework, we elaborate the ecosystem's systemic structure in the international entrepreneurship context to comprehend the relevance of such elements for the wider setting and mainly for BGs. All the systemic elements have received attention in the international entrepreneurship literature (e.g., leadership, see Mets, 2015; financial capital, see Gabrielsson et al., 2004, 2008; talent, see Jantunen et al., 2008; Luostarinen and Gabrielsson, 2004; networks, see Gabrielsson and Kirpalani, 2004; Laanti et al., 2007; knowledge, see Gabrielsson et al., 2008; Loane et al., 2007; Rialp et al., 2012; support, see Harrington, 2017; Pauwels et al., 2016). However, these studies have tended to examine only one or a couple of the systemic elements at a time, thus neglecting the role of the entrepreneurial ecosystem from a holistic point of view, which would thus enable considering the effects of all its respective elements. Hence, it is important to clarify how a transnational ecosystem powers entrepreneurial internationalisation (Andersson et al., 2013; Coviello, 2006) and to elaborate 
the relations between the structure of the system and its influence on the development and subsequent value for potential BG firms (Borissenko and Boschma, 2017; Spigel, 2015; Stam, 2015).

There are six main domains of systemic elements (Stam, 2014) and it is necessary to subdivide some of them to elaborate their relevance for the life-cycle stages of the BGs (Velt et al., 2018b). These elements are entrepreneurial leadership, financial capital sub-elements, two types of talent, knowledge as a singular concept, networks and sub-elements of the support services. Therefore, we briefly explain all of them, starting with entrepreneurial leadership, which is defined as "influencing and directing the performance of group members toward the achievement of organisational goals that involve recognising and exploring entrepreneurial opportunities" (Renko et al., 2015, p. 55). In the context of this study, this leadership is visible in the ecosystem, as established entrepreneurs motivate others to follow in their footsteps. Also, it trickles down to the firm level as the founders reflect their leadership abilities on their team members. These entrepreneurial leaders are crucial for a healthy ecosystem to create strong firms (Feld, 2012; Mets, 2015; Vissak, 2007).

Furthermore, financial capital is one of the main topics affecting firm growth and progress (Gabrielsson et al., 2004). There are multiple ways to raise capital or to secure financial resources creatively without lending money or selling equity such as empowering bootstrapping or minimising funding need (Harrison et al., 2004). Yet, in the context of rapidly evolving BG startups, the founders need to raise capital from lenders (e.g. credit institutions, family and friends) and from equity investors (e.g. business angels [BAs], venture capitalists). Lenders usually use official collateral requirements to allocate a credit line and run their due diligence to assess the risks (Winton and Yerramilli, 2008). However, family and friends behave similarly (Chua et al., 2011; Wu et al., 2016) while using trust as a form of collateral. Also, it is not only about lending, but possessing an equity stake to support activities. However, such sources should not be considered as strategic partners, like BAs, who use a hands-on approach to improve the firm's survival (Kerr et al., 2014) by providing "seed capital” (Wong et al., 2009). Similarly, venture capital (VC) firms and corporate VC (CVC) investors utilise their networks to back their investment and use their extensive knowledge and capabilities to enhance the success of the firms (Denis, 2004; Kaplan and Strömberg, 2000). The main difference with the latter two is that CVC investors have corporate agendas and often integrate the focal company into their business platform ecosystem (e.g. iOS, Amazon). In addition, the most recent concept of 
"crowdfunding" is a way to raise capital from many individuals over the internet at once (Mollick, 2014) and has become a valid substitute for other forms of capital sources.

Moreover, every city, region and country has its own talent pool that is considered a critical resource for firm development and consequent success in the ecosystem (Cohen, 2006; Stam, 2014). Hence, talent is fundamental for creating entrepreneurial activities and often becomes visible in diverse and open societies (Lee et al., 2004), thus talented individuals attract others to join their efforts in creating a sustainable environment to thrive in (Bahrami and Evans, 1995; Cohen, 2006). In addition, welcoming societies have an agglomeration of such talent, which creates the right conditions for the launch and growth of new ventures (Thomas et al., 2015). However, when the opposite deglomeration occurs, potential entrepreneurs tend to move out from such environments to establish their businesses in another location where there is an abundance of talented people to hire and collaborate with (Neck et al., 2004), thus making talent critical for new venture success (Foster et al., 2014).

Correspondingly, with the movement of talent, specific and appropriate knowledge moves into the entrepreneurial ecosystem. The knowledge build-up under resource constraints (Oviatt and McDougall, 1994) helps in recognising opportunities, which entrepreneurs then exploit by creating new innovations and building firms around novel solutions. However, knowledge creation does not usually happen in isolation (Huggins and Thompson, 2015), rather the entities capture the knowledge spill-overs by externally screening for innovations (Katila, 2002). Thus, entrepreneurs recognise opportunities by exploiting these spill-overs and then create new ventures to convert this revealed knowledge into commercial knowledge (Ács et al., 2013). In parallel, the needed knowledge, information, resources, activities and capabilities are shared and acquired from a complex set of relationships among the entrepreneurs and network participants. Thus, there is a need for established networks that are "defined by the enduring exchange relations established between organisations, individuals and groups" (Weber and Khademian, 2008, p. 334) inside and extending outside of the local entrepreneurial ecosystem.

Last of all, there is a set of support conditions that needs to be present to cater to the needs of entrepreneurial firms such as consulting services, intermediaries, networking providers and engagement events. Consultants are "a sophisticated service infrastructure [that] allows start-up firms to focus on their chosen steeple of expertise, rather than dissipate their energies across a broad range of peripheral or supporting activities" (Bahrami and Evans, 1995, p. 63), meaning 
that entrepreneurs should focus on their core activities and outsource the rest. Zhang and Li (2010) argued that firms' innovation capability is related to professionals who share new knowledge, information on inventions, and reduce costs (McEvily and Zaheer, 1999) and mitigate the risks of disrupting the innovation process (Saxenian, 1990).

Similarly, intermediaries provide "support to start-ups to improve the probability of survival of the portfolio companies and accelerate their development" (Pauwels et al., 2016, p. 14). Incubators target very early-stage firms with greenhorn founders with scalable business models (Isabelle, 2013; Stagars, 2015) and accelerators focus on already established fast-tracking knowledge-intensive ventures (Bosma and Stam, 2012; Pauwels et al., 2016) by validating their businesses. Likewise, there is a set of network mediators (e.g. industry associations, alumni) which provides networking support and smoothens out information exchange and other interactions (Howells, 2006; Suresh and Ramraj, 2012) to enable new firms to gather the required resources. In addition, engagement services play a crucial role in motivating firms to launch. These meeting events enable entrepreneurs and community members to collaborate, initiate, pursue and combine new innovations (e.g. via start-up weekends and hackathons) (Feld, 2012; Harrington, 2017).

In sum, all the above-mentioned elements reflect the ecosystem's moral and inspirational conditions and highlight the value of the resources essential for developing business proposals based on the newest technological advancements. These forces are accessed, enriched, upheld and enabled by relationships between stakeholders, who in turn are supported early on to reach sustainable growth and development in the transnational entrepreneurial-ecosystem setting.

\section{RESEARCH METHODOLOGY}

The list of BG start-ups for the empirical part of this study was extracted and combined from a set of secondary sources: Startup 100, Crunchbase, FunderBeam and ActicStartup. All the firms found in the databases have been certified by start-up community leaders and investors, affirming that these firms possess the potential to become next-generation BG ventures. We introduced the stratified sampling method (cf. Neyman, 1934) to only target firms that had reached the second life-cycle phase to account for their timely knowledge regarding the preliminary stages of discovery and validation. Further, we applied the online survey method and managed 
to gather responses from 51 founders from Finland and 33 from Estonia. As the sample collection only targeted BG start-ups, we then verified their speed of internationalisation, market scope and export extent (Kuivalainen et al., 2012). However, we were less strict regarding the requirement for BG to be present in at least two continents (cf. Luostarinen and Gabrielsson, 2006; Nummela et al., 2014) as this has a marginal effect on smaller economies (Choquette et al., 2017). In addition, as we were looking at the first stages of the life-cycle, some of the firms had no revenue as they were still less than 3 years old and had become international via other value-chain activities (e.g., global team allocation, joining a platform ecosystem).

Additionally, we controlled for the common method bias (Podsakoff et al., 2003). When composing the survey, it was important to elaborate the elements and split some of them into subelements (i.e., financial capital, talent and support systems) to make clear distinctions and comparisons. Hence, this distinction ensured that the respondents would assess the elements as objectively as possible based on their own experience, allowing for the mitigation of the common method bias risk. In addition, we conducted Harman's single factor test and did not detect any individual factor that was solely influencing the results. Hence, we argue that there were no obvious issues with the common method bias.

Furthermore, we developed a set of metrics (cf. Audretsch and Belitski, 2017; Corrente et al., 2018; Liguori et al., 2019) measuring the elements and sub-elements on a scale from 0 to 100. This allowed us to clearly demonstrate which elements were ranked as essential for the preliminary stages of the BG life-cycle. Then, to answer RQ1, all mean averages were calculated for each element in its respective stage for both countries combined. These mean values were then used to calculate the aggregate equivalents as cut-off points to distinguish the critical elements from the non-critical ones associated with the firm's progress.

Thereafter, to answer RQ2, we collected data on multiple characteristics of the entrepreneurial firms regarding their organisational (i.e., age, team size, service-product orientation, revenue) and international features (i.e., team allocation, origin of the owners, speed of internationalisation, market scope) and divided the firms into binary groups. These characteristics elaborate how ecosystem elements have influenced BG development. We then applied an analysis of variance (ANOVA) to compare the statistical significance of the entrepreneurial perceptions to verify if there were any discrepancies in terms of how these firms interpreted their environment. Resulting from the above steps, we could then answer the RQs by identifying which elements 
were most critical for firm development and how BGs were influenced by the ecosystem during life-cycle stages, depending on their characteristics.

\section{FINDINGS}

The findings were divided into two sections corresponding to the RQs (see Table 1 below). In the first section, we arranged the elements in descending order based on their mean average values. This was essential to visualise the position of the elements and their rank in both stages. Then, after calculating the cut-off points, it became clear that there were six elements that were critical for the stages (i.e., entrepreneurial talent, knowledge, leadership, networks, worker talent and BAs), five were non-critical for progress (i.e., intermediaries, networking services, crowdfunding, CVC, credit institution) and five were in a transition mode (i.e., informal debt, bootstrapping, engagement services, consultants, VC). In terms of the latter elements, their positions changed by around ten places with a deviation of up to 31.67 points (i.e. VC), indicating that the elements' configuration for BG development effectively changed when they moved from one stage to the other.

(Insert Table 1 here)

Furthermore, in the second section, it was imperative to explore if there was any contrast in these perceived rankings. Ergo, we needed to analyse firms' intra-group variance to detect if there was any disparity among their characteristics. We applied the ANOVA method to analyse the 16 ecosystem elements in the context of $8 \mathrm{BG}$ attributes. Intra-group variance was detected for more than half of the elements, indicating that firms had assorted perceptions towards their entrepreneurial ecosystem. We found 9 distinctions in the discovery stage and 7 in the validations stage, of which 2 were statistically significant at the $1 \%$ level and 14 were significant at the 5\% level. However, the ANOVA results explain the background of the relationship as none of the intra-group perceptions changed the ranking from critical to non-critical and vice versa. In addition, the correlation coefficients were not measurable because we compared continuous dependent variables with binary independent variables and thus utilised point-scale deviations to demonstrate their significance. 
In summary, the above results revealed that some elements were more critical than others under transnational conditions, and intra-group variations explained the contextual differences in how these elements influenced BG launches and their consequent internationalisation. All these results will now be discussed in detail.

\section{DISCUSSION}

The RQs of this study examine the ecosystem elements by exploring their criticality levels for BG development and how BGs perceive these elements in various ways depending on their intra-group characteristics. Also, it is rational to discuss each element independently in the transnational entrepreneurial-ecosystem context to attain a sound outline of the results.

\section{Leadership}

Leadership (particularly entrepreneurial leaders in the ecosystem context) is considered as influential individuals who share their experience in discovering and exploiting opportunities for value creation with their community and indirectly with the rest of the world (Greenberg et al., 2011). In this study framework, it became clear that the leadership element was critical for BG development in the preliminary stages. This stable influence is in line with the previous research indicating that entrepreneurial leaders should become role models for others and motivate them (McGrath and MacMillan, 2013) to embrace creativity (Cardon et al., 2009) and work towards entrepreneurial objectives and activities (Gupta et al., 2004; Yukl, 2008). However, leadership in some sense is limited to the local context, thus this is why the ANOVA results indicated that BGs with local teams were more exposed to the leadership element during validation processes. From another perspective, BGs with team members allocated across borders have arguably commenced internationalisation activities and therefore perceive leadership as less critical for the validation stage. The above results are in line with Mets (2015), who argued that leadership is a main factor for early internationalisation, hence its high ranking in both stages and the visible discrepancy for already internationalised firms.

\section{Finance}

Entrepreneurial finance focuses on BGs' decision to raise financial capital. Entrepreneurs create innovations and transform these into viable products and services (Burgelman and Hitt, 2007). As this process is time-dependant (Suddaby et al., 2015) and requires immense amounts of capital investment (Ebben and Johnson, 2006), this action of commercialisation (Luostarinen and Gabrielsson, 2006) makes financial capital a primary element for progress. Overall, our 
results are in line with the above reasoning as some elements are efficient in the first stage and others in the second. However, as there are multiple sources of capital, it is crucial to explore which of them matter for BGs.

Our results suggest that informal debt and bootstrapping are critical for the discovery stage, but as they cannot cope with the speed of commercialisation and the cash burn-rate, these elements become non-critical for the validation stage. The ANOVA suggests that younger BGs value informal debt as more critical than older BGs do. This clearly indicates that high-risk investments and raising capital from the inner circle have been accepted by the local community to support BG development. Confidence is determined as collateral and failures are accepted as part of the learning process. In addition, it is interesting to note that BGs with foreign equity investors perceive informal debt as more critical. Perhaps founders with solid business plans are confident in raising capital from their family and friends, as otherwise they would risk harming their relationships. Thus, this degree of legitimacy generates trust among and is attractive to professional investors.

Moreover, BAs and VC are more suited for commercialisation in the second stage, as they improve firm survival, integrate new talent and lead to higher online visibility and traction, while simultaneously consulting and extending founders' networks (Kerr et al., 2014; Luostarinen and Gabrielsson, 2006). Our results indicate that BAs are critical in both stages as they are considered as the region's own private investors who invest "seed capital" (Chemmanur and Fulghieri, 2014; Wong et al., 2009) and support the development from there. This is visible in the validation stage, as the results demonstrate that younger start-ups perceive BAs as more critical, denoting that these consortiums of investors have become a suitable source of finance for BG growth. However, BGs that have internationalised during their first year after inception find BAs less critical than others do. This is an indication that BAs have tendencies to constrain aggressive scaling, which instead is in line with the strategies of VC (Gabrielsson et al., 2004). Thus, our results clearly support the previous statement that VC is one of the principal elements in the validation stage and a prerequisite for successful internationalisation. Nevertheless, intra-group perceptions reveal that VC is more critical for BGs with foreign equity shareholders in the first stage compared to BGs with only local owners. This suggests that BGs backed by foreign equity owners are more open, have already attracted VC funding (Gabrielsson et al., 2008), or local founders just might feel reluctant to share their business in the discovery stage, or the BG business model is not yet suited to VC strategies. 
Other sources such as crowdfunding, CVC and credit institutions were not found to be critical in supporting BG development. Crowdfunding is one of the newest popular ways to raise funding (Mollick, 2014), however, as it is rather understudied (Maroufkhani et al., 2018), our results suggest that there might be a mismatch between "smart" and "capital" for founders, making such online platforms non-critical. We argue that the information potential investors receive is ambiguous, that they might easily lose their money due to high default rates, and for the founders, it does not include the required benefits of monitoring, advising, teaching, recruiting and connecting with the right people when compared to VC and BAs (Chemmanur and Fulghieri, 2014).

CVC is also seen as less critical, which might be due to its formal strategy of only targeting BGs suitable for longitudinal investment plans and aligned with corporate strategies. The ANOVA reveals that $\mathrm{CVC}$ is attractive for BGs with foreign equity owners, similarly to $\mathrm{VC}$, except CVC's strategic position differs. However, an interesting find is that BGs with pre-revenue status perceive CVC as more critical for their discovery stage than those with revenue do. The simplest explanation could be that CVC firms only target BGs that can be integrated into their business platform ecosystems (e.g. Skype and Microsoft, WhatsApp and Facebook), making other BGs in the sample rank them less critically. As BG development incorporates high levels of uncertainty and risk (Gabrielsson et al., 2008), we argue that firms with complex products-services and longer R\&D time horizons perceive CVC as a stable environment, where the focus is on building meaningful solutions for platform bundling and is less on making money straight away.

Lastly, the results show that credit institutions were ranked as the lowest form of capital source, arguably because first-time entrepreneurs lack the collateral instruments and proven track record, thus making them less attractive for the credit institutions (Zott and Huy, 2007). This is further verified by the intra-group perspectives, as highly rapid internationalising firms perceived these institutions as inhibitors of internationalisation compared to standard BGs, probably because any kind of a constraint on cash flow would hinder momentum and progress. Concluding the results on capital sources, it is apparent that informal types of funding are more critical in the first stage, formal ones for scaling and internationalisation, and traditional and online institutions were not seen as critical for BG development because they lack the handson approach, personal connection and cannot directly commit to the success of the new venture. 


\section{Talent}

Talent is one of the main resources for firm development, as entrepreneurs are the ones initiating BGs and driving them, while worker talent is considered as a spectrum of specialists in their respective fields who join the venture when the tasks become too complex for the founders to handle alone. Hence, there is a direct connection between talent and well-performing start-ups (Rauch and Rijsdijk, 2013; Talaia et al., 2016).

The results indicate that entrepreneurial talent is the most critical element in BG development in both stages. The statement that founders with proactive mindsets search for opportunities and create innovations while taking a substantial risk (cf. Kuivalainen et al., 2007; Nummela et al., 2004; Vissak, 2007) received support in the empirical analysis. Worker talent is slightly less critical in the discovery stage but becomes highly critical when validation begins. Hence, founders take charge in the first stage and as the processes become more complex, talented people will be integrated to create synergies and together confront the challenges.

\section{Knowledge}

Knowledge is the fundamental source and driving force of modern communities shaped by dynamic innovation processes (Ács et al., 2016). BGs leverage their inner capabilities to learn and create new knowledge to develop unique and specialised products and services (Gabrielsson and Kirpalani, 2004). Our results confirm that knowledge accumulation is highly critical for both stages. However, there are some intra-group differences. In the discovery stage, for younger firms, specific knowledge is essential, but other abilities (e.g., raising less restrictive capital, composing a team and extending networks) also take on a principal role during firm establishment. In contrast, BGs with larger teams perceive knowledge as more critical than smaller ones do. Arguably, the more sophisticated the business model becomes, the more talent with appropriate knowledge is integrated, making the team's composition and volume essential to run the tasks. In the validation stage, BGs with revenue streams perceive knowledge as less critical compared to pre-revenue firms. The difference in perception could be based on the timeline, as pre-revenue firms can still conduct knowledge-intensive R\&D activities. Hence, as the product-service is not yet marketable, revenue is absent. Similarly, service-oriented BGs stated that knowledge was more critical than for product-oriented ventures. We suggest that service firms are vulnerable to demand fluctuations due to their shorter time-to-market periods, making them arbitrarily flexible so that they can respond promptly to constantly changing market requirements. In addition, firms with more than ten markets perceive knowledge as more critical. Resilient international aspirations require a certain mix of knowledge and capabilities 
to retain a strong market presence (Rialp et al., 2012). Thus, expansion via learning-by-doing is a distinctive factor for BGs with a stronger market presence.

\section{Networks}

Networks are relational structures which entrepreneurs and other community participants engage inside and outside the local ecosystem to link and share information, activities, resources and capabilities to fulfil the requirements for BG development (cf. Mort and Weerawardena, 2006; Zhou et al., 2007). The results from this study confirm that the network element in the ecosystem is also critical for the early development of BGs in both stages. This is in line with the results from previous research arguing that there is a direct connection between building and leveraging networks in the early stages to sustain successful growth (Gabrielsson and Kirpalani, 2004; Laanti et al., 2007) and facilitate rapid internationalisation (Gabrielsson et al., 2008).

\section{Support services}

Support services play a crucial role in sustaining the development and speeding up internationalisation for BG-type start-ups (Zhang and Li, 2010). Our study concentrated on the elements of consultants, intermediaries, networking and engagement services. Consultants, a set of external specialists, deliver different kinds of support services to BGs, so the teams can concentrate on what matters the most and less on bureaucracy. According to the results, these services were non-critical during the first stage and critical in the second stage. Hence, this corresponds to the idea that BGs handle their issues themselves in the beginning, however, external help becomes more relevant when complexities increase and different support and professional services are looked for (Luostarinen and Gabrielsson, 2006).

Furthermore, intermediaries such as incubators and accelerators form micro-ecosystems to integrate BG start-ups. In both stages, these mediators were ranked just below the cut-off line, making them non-critical for supporting BG development. Previous research has found that these intermediaries play a critical role in firm development and in improving their survival rates and accelerating their development (Feld, 2012; Pauwels et al., 2016). Our argument is that as we focus on small economies, their relative insufficiencies are visible on the incubator and accelerator level. In other words, when the local environment functions under resource constraints and shorter external networks, these micro-entities encounter comparable issues. Hence, the quality and quantity of intermediaries reflects the quaintness of the local ecosystem. 
Networking services support entrepreneurs to find needed resources from their own networks and mediate information and other exchanges to enable further development. From the results, these services were found to be non-critical, but they still influenced and benefited the ecosystem (Saxenian, 1990; Suresh and Ramraj, 2012). We suggest this is because these services do not satisfy the BG requirements as ecosystems in periphery regions have shorter network nodes. The intra-group difference shows that, during the discovery stage, firms with foreign equity investors view networking services as more critical than others do. Hence, we argue that foreign stakeholders themselves can behave as the network extension for the firm. These services (e.g. alumni organisations) might in fact have been the key for foreign capital entry in the first place.

Lastly, engagement events are held to build social relationships between entrepreneurs and other community contributors to uncover and pursue innovation frontiers. We realised that engagement services are critical in the discovery stage and non-critical during validation. Hence, these events are appropriate for creating new BGs, but less relevant for validating the business ideas and finding new team members and investors. Previous studies have made clear that these events are significant to healthy ecosystems (Feld, 2012; Harrington, 2017). The ANOVA detected that BGs with revenue streams perceived these events as more critical in the discovery stage than the pre-revenue firms did. This difference explicitly shows that BG participation has a positive effect on achieving revenue streams. Hence, the appropriate team composition and generating captivating business propositions lead to successful sales activities. In sum, even though some of the elements were not depicted to be as critical as others were, they are all relevant in forming and sustaining a healthy entrepreneurial ecosystem in the transnational setting.

\section{CONCLUSION}

Reflecting on the decades of research on entrepreneurial environments, scholars have studied how to nurture entrepreneurial action in various ways. One of these focal points has been the entrepreneurial-ecosystem construct, which, unlike others, directly influences entrepreneurial activities in launching and growing rapidly internationalising firms. These systems consist of structural elements that each play their role in fostering the needs of a new venture. Therefore, our exploratory study aimed to shed more light on the arrangements in terms of how these ecosystems influence BG start-ups during the preliminary stages of a firm's life-cycle. We took the transnational viewpoint of two small economies sharing their regional resources, thus unintentionally converging their environments towards a more sustainable arrangement. 


\section{Theoretical contribution}

The entrepreneurial-ecosystem construct is a topic that has gained momentum in recent years, as researchers, practitioners and policy makers, among others, would like to figure out how to construct and sustain environments that are innovation-driven and focus on value creation for the global society. Therefore, we wanted to explore the topic by integrating the entrepreneurial ecosystem, BGs and life-cycle studies into one framework to comprehend how the ecosystem's structural elements influence the development of rapidly internationalising firms during their stages of life (Alvedalen and Boschma, 2017; Malecki, 2018). This framework is not new per se (cf. Velt et al., 2018b, 2018a), however, it takes an original perspective. Specifically, we integrate a new dimension of "transnational" into the entrepreneurial-ecosystem context. The relevance is that we focus on two countries that have a high concentration of BG start-ups, and as these economies are situated in close proximity, there is an allusion of convergence. This opens a new study avenue to explore transnational aspects of the ecosystems, but also the effects of regional agglomeration and successive deglomeration.

Furthermore, we assessed the ecosystem level in a balanced manner (Mack and Mayer, 2016) by analysing all the main elements in one study framework and concentrating on the combined perceptions of BG founders to elaborate how these entrepreneurs sense their transnational environment. In detail, we focused on the configurations of criticality (Cavallo et al., 2018) to see which systemic elements were necessary in the regional context to support rapidly internationalising firms. It was appropriate to elaborate these criticality levels based on the intra-group differences of the firms to gather new insights into which elements and their combinations in the various stages should be emphasised to improve the nurturing surroundings when launching new ventures with global aspirations. The division of the stages exposed an increasingly complex view of ecosystem interactions.

\section{Practical implications}

For entrepreneurs, our results elaborate how the transnational ecosystem behaves in a regional setting. Defining the critical elements in the preliminary stages would familiarise ecosystem participants regarding where the emphasis should be directed when launching and growing new ventures. These results inaugurate a layout of the ecosystem so that novice entrepreneurs can clearly identify where to allocate their time and effort. For example, they should try to raise capital from established sources such as BAs and VC, rather than spending time with credit 
institutions and crowdfunding. Similarly, the firm's business model and strategy implementations play a crucial role in the success of a venture, thus, participating in the engagement events will raise the firm's potential to better secure revenue streams.

For governments and policy makers, they should try to create a supportive set of regulations that will counter the shortcomings of the local entrepreneurial environment. As the discussion is about the formulation of a transnational setting, all relevant institutions should start to align their goals and introduce common strategies to benefit the regional ecosystem. For example, the free movement of talent between the countries happens daily, however, it is not easy for start-ups to officially relocate as corporate regulations and laws are rather different. Hence, it is important to create a common framework and support the set-up for rapidly internationalising firms as they are on the frontline of creating new jobs and societal value. It would be a strong advantage for Finnish ICT start-ups to directly hire Estonian talent for their e-governance units without having to deal with tax-compliance issues, or for a new Estonian gene-tech firm to apply for funding from Finnish state grants as there is no considerable equivalent in Estonia. Thus, creating common policies would benefit both nations in the long-run by sharing the innovation capacity.

\section{Limitations and future research}

The current study is exploratory and stays relatively descriptive by focusing on the best-in-theclass firms such as BGs. Hence, there should be other studies introducing and comparing the perceptions of other types of firms which are rapidly internationalising but have not achieved BG status. Likewise, based on the firm type, a configuration study would be of great benefit to reveal the modifications of the ecosystem elements required. In addition, it is essential to dig deeper and prepare case studies to understand more about the founders' experience in terms of why some elements are more critical than others are and how intra-group differences have played out in real life.

Additionally, by introducing the transnational dimension into the framework, we open a new avenue for research. Yet, as this is the first study to propose this, we need to verify that transnationality fully applies to the entrepreneurial-ecosystem context. The main dispute could be that transnationality is suitable in a small-economy context where the ecosystem is more often defined on the country level. But, for example, if we address a large economy on a state level that is the size of a country, the local ecosystem does not extend beyond national borders. However, cross-border convergence still occurs, but not outside the country limits. 


\section{References}

Ács, Z.J., Audretsch, D.B., Lehmann, E.E., 2013. The knowledge spillover theory of entrepreneurship. Small Business Economics 41, 757-774.

Ács, Z.J., Estrin, S., Mickiewicz, T., Szerb, L., 2017. Institutions, entrepreneurship and growth: the role of national entrepreneurial ecosystems.

Ács, Z.J., Szerb, L., Lafuente, E., Lloyd, A., 2018. The Entrepreneurial Ecosystem and Global Prosperity, in: Ács, Z.J., Szerb, L., Lafuente, E., Lloyd, A. (Eds.), Global Entrepreneurship and Development Index 2018. Springer International Publishing, Cham, pp. 1119. https://doi.org/10.1007/978-3-030-03279-1_2

Alvedalen, J., Boschma, R., 2017. A critical review of entrepreneurial ecosystems research: towards a future research agenda. European Planning Studies 25, 887-903.

Andersson, S., Evers, N., Griot, C., 2013. Local and international networks in small firm internationalization: cases from the Rhône-Alpes medical technology regional cluster. Entrepreneurship \& Regional Development 25, 867-888.

Audretsch, D.B., Belitski, M., 2017. Entrepreneurial ecosystems in cities: establishing the framework conditions. The Journal of Technology Transfer 42, 1030-1051.

Autio, E., Nambisan, S., Thomas, L.D., Wright, M., 2018. Digital affordances, spatial affordances, and the genesis of entrepreneurial ecosystems. Strategic Entrepreneurship Journal 12, 72-95.

Bahrami, H., Evans, S., 1995. Flexible Re-Cycling and High-Technology Entrepreneurship. California Management Review 37, 62-89. https://doi.org/10.2307/41165799

Bailetti, E., 2018. Transnational Entrepreneurship: Distinctive Features and a New Definition. Technology Innovation Management Review 8, 28-38. https://doi.org/10.22215/timreview/1184

Borissenko, J., Boschma, R., 2017. A critical review of entrepreneurial ecosystems research: towards a future research agenda. Lund University, CIRCLE-Center for Innovation, Research and Competences in the Learning Economy.

Bosma, N., Stam, E., 2012. Local policies for high-employment growth enterprises, in: Report Prepared for the OECD/DBA International Workshop on High-Growth Firms: Local Policies and Local Determinants, Copenhagen.

Burgelman, R.A., Hitt, M.A., 2007. Entrepreneurial actions, innovation, and appropriability. Strategic Entrepreneurship Journal 1, 349-352.

Cannone, G., Ughetto, E., 2014. Born globals: A cross-country survey on high-tech start-ups. International Business Review 23, 272-283.

Cardon, M.S., Wincent, J., Singh, J., Drnovsek, M., 2009. The nature and experience of entrepreneurial passion. Academy of management Review 34, 511-532.

Cavallo, A., Ghezzi, A., Balocco, R., 2018. Entrepreneurial ecosystem research: present debates and future directions. International Entrepreneurship and Management Journal 1-31.

Cavusgil, S.T., Knight, G., 2015. The born global firm: An entrepreneurial and capabilities perspective on early and rapid internationalization. Journal of International Business Studies 46, 3-16.

Chemmanur, T.J., Fulghieri, P., 2014. Entrepreneurial finance and innovation: An introduction and agenda for future research. Review of Financial Studies 27, 1-19.

Choquette, E., Rask, M., Sala, D., Schröder, P., 2017. Born Globals-Is there fire behind the smoke? International Business Review 26, 448-460.

Chua, J.H., Chrisman, J.J., Kellermanns, F., Wu, Z., 2011. Family involvement and new venture debt financing. Journal of Business Venturing 26, 472-488. https://doi.org/10.1016/j.jbusvent.2009.11.002 
Cohen, B., 2006. Sustainable valley entrepreneurial ecosystems. Business Strategy and the Environment 15, 1-14. https://doi.org/10.1002/bse.428

Corrente, S., Greco, S., Nicotra, M., Romano, M., Schillaci, C.E., 2018. Evaluating and comparing entrepreneurial ecosystems using SMAA and SMAA-S. The Journal of Technology Transfer 1-35.

Coviello, N.E., 2006. The Network Dynamics of International New Ventures. Journal of International Business Studies 37, 713-731.

Denis, D.J., 2004. Entrepreneurial finance: an overview of the issues and evidence. Journal of Corporate Finance 10, 301-326. https://doi.org/10.1016/S0929-1199(03)00059-2

Ebben, J., Johnson, A., 2006. Bootstrapping in small firms: An empirical analysis of change over time. Journal of Business Venturing 21, 851-865.

European Union, 2012. TFEU [WWW Document]. URL https://eur-lex.europa.eu/legal-content/EN/TXT/?uri=uriserv:OJ.C_.2012.326.01.0001.01.ENG\&toc=OJ:C:2012:326:TOC (accessed 1.29.19).

Feld, B., 2012. Startup communities: building an entrepreneurial ecosystem in your city. John Wiley \& Sons, Inc, Hoboken, New Jersey.

Foster, G., Shimizu, C., Pinell, M., Cunningham, J., 2014. Entrepreneurial Ecosystems Around the Globe and Early-Stage Company Growth Dynamics. World Economic Forum.

Gabrielsson, M., Kirpalani, V.M., 2004. Born globals: how to reach new business space rapidly. International Business Review 13, 555-571.

Gabrielsson, M., Kirpalani, V.M., Dimitratos, P., Solberg, C.A., Zucchella, A., 2008. Born globals: Propositions to help advance the theory. International Business Review 17, 385-401.

Gabrielsson, M., Sasi, V., Darling, J., 2004. Finance strategies of rapidly-growing Finnish SMEs: born internationals and born globals. European Business Review 16, 590-604.

Greenberg, D., McKone-Sweet, K., Wilson, H.J., 2011. The New Entrepreneurial Leader: Developing Leaders Who Shape Social and Economic Opportunity. Berrett-Koehler Publishers.

Gupta, V., MacMillan, I.C., Surie, G., 2004. Entrepreneurial leadership: developing and measuring a cross-cultural construct. Journal of Business Venturing 19, 241-260.

Harrington, K., 2017. Entrepreneurial Ecosystem Momentum and Maturity the Important Role of Entrepreneur Development Organizations and Their Activities.

Harrison, R.T., Mason, C.M., Girling, P., 2004. Financial bootstrapping and venture development in the software industry. Entrepreneurship \& Regional Development 16, 307-333. https://doi.org/10.1080/0898562042000263276

Howells, J., 2006. Intermediation and the role of intermediaries in innovation. Research policy $35,715-728$.

Huggins, R., Thompson, P., 2015. Entrepreneurship, innovation and regional growth: a network theory. Small Business Economics 45, 103-128. https://doi.org/10.1007/s11187-0159643-3

Isabelle, D.A., 2013. Key Factors Affecting a Technology Entrepreneur's Choice of Incubator or Accelerator. Technology Innovation Management Review 3, 16.

Jantunen, A., Nummela, N., Puumalainen, K., Saarenketo, S., 2008. Strategic orientations of born globals-Do they really matter? Journal of World Business 43, 158-170. https://doi.org/10.1016/j.jwb.2007.11.015

Kaplan, S.N., Strömberg, P., 2000. How do venture capitalists choose investments. Workng Paper, University of Chicago 121, 55-93.

Katila, R., 2002. New product search over time: past ideas in their prime? Academy of Management Journal 45, 995-1010.

Kerr, W.R., Lerner, J., Schoar, A., 2014. The consequences of entrepreneurial finance. 
Knight, G.A., Cavusgil, S.T., 2005. A taxonomy of born-global firms. MIR: Management International Review 15-35.

Kshetri, N., 2014. Developing successful entrepreneurial ecosystems: Lessons from a comparison of an Asian tiger and a Baltic tiger. Baltic Journal of Management 9, 330-356. https://doi.org/10.1108/BJM-09-2013-0146

Kuivalainen, O., Saarenketo, S., Puumalainen, K., 2012. Start-up patterns of internationalization: A framework and its application in the context of knowledge-intensive SMEs. European Management Journal 30, 372-385.

Kuivalainen, O., Sundqvist, S., Servais, P., 2007. Firms' degree of born-globalness, international entrepreneurial orientation and export performance. Journal of World Business, The Early and Rapid Internationalization of the Firm 42, 253-267. https://doi.org/10.1016/j.jwb.2007.04.010

Laanti, R., Gabrielsson, M., Gabrielsson, P., 2007. The globalization strategies of business-tobusiness born global firms in the wireless technology industry. Industrial Marketing Management 36, 1104-1117.

Lee, S.Y., Florida, R., Ács, Z., 2004. Creativity and entrepreneurship: A regional analysis of new firm formation. Regional studies 38, 879-891.

Liguori, E., Bendickson, J., Solomon, S., McDowell, W.C., 2019. Development of a multidimensional measure for assessing entrepreneurial ecosystems. Entrepreneurship \& Regional Development 31, 7-21. https://doi.org/10.1080/08985626.2018.1537144

Loane, S., Bell, J.D., McNaughton, R., 2007. A cross-national study on the impact of management teams on the rapid internationalization of small firms. Journal of World Business 42, 489-504. https://doi.org/10.1016/j.jwb.2007.06.009

Lundberg, H., Rehnfors, A., 2018. Transnational entrepreneurship: opportunity identification and venture creation. J Int Entrep 16, 150-175. https://doi.org/10.1007/s10843-0180228-5

Luostarinen, R., Gabrielsson, M., 2006. Globalization and marketing strategies of born globals in SMOPECs. Thunderbird International Business Review 48, 773-801.

Luostarinen, R., Gabrielsson, M., 2004. 22 Finnish perspectives of international entrepreneurship. Handbook of research on international entrepreneurship 383.

Mack, E., Mayer, H., 2016. The evolutionary dynamics of entrepreneurial ecosystems. Urban Studies 53, 2118-2133. https://doi.org/10.1177/0042098015586547

Malecki, E.J., 2018. Entrepreneurship and entrepreneurial ecosystems. Geography compass 12, e12359.

Marmer, M., Herrmann, B.L., Dogrultan, E., Berman, R., 2011. A new framework for understanding why startups succeed.

Maroufkhani, P., Wagner, R., Wan Ismail, W.K., 2018. Entrepreneurial ecosystems: a systematic review. Journal of Enterprising Communities: People and Places in the Global Economy 12, 545-564.

Mason, C., Brown, R., 2014. Entrepreneurial ecosystems and growth oriented entrepreneurship. Final Report to OECD, Paris.

McEvily, B., Zaheer, A., 1999. Bridging ties: A source of firm heterogeneity in competitive capabilities. Strategic management journal 1133-1156.

McGrath, R.G., MacMillan, I., 2013. The Entrepreneurial Mindset: Strategies for Continuously Creating Opportunity in an Age of Uncertainty. Harvard Business Press.

Mets, T., 2015. The Role of Leadership in Hi-Tech Born-Globals: Small Emerging Country Cases, in: ICMLG2015-The 3rd International Conference on Management, Leadership and Governance: ICMLG2015. Academic Conferences and Publishing Limited, p. 207.

Mollick, E., 2014. The dynamics of crowdfunding: An exploratory study. Journal of Business Venturing 29, 1-16. https://doi.org/10.1016/j.jbusvent.2013.06.005 
Moore, J.F., 1993. Predators and prey: a new ecology of competition. Harvard business review $71,75$.

Mort, G.S., Weerawardena, J., 2006. Networking capability and international entrepreneurship: How networks function in Australian born global firms. International Marketing Review 23, 549-572. https://doi.org/10.1108/02651330610703445

Nauwelaers, C., Maguire, K., Marsan, G.A., 2013. The Case of Helsinki-Tallinn (Finland-Estonia) - Regions and Innovation: Collaborating Across Borders. https://doi.org/10.1787/5k3xv01rt1r6-en

Neck, H.M., Meyer, G.D., Cohen, B., Corbett, A.C., 2004. An entrepreneurial system view of new venture creation. Journal of Small Business Management 42, 190-208.

Neyman, J., 1934. On the two different aspects of the representative method: the method of stratified sampling and the method of purposive selection. Journal of the Royal Statistical Society 97, 558-625.

Nummela, N., Saarenketo, S., Jokela, P., Loane, S., 2014. Strategic decision-making of a born global: A comparative study from three small open economies. Management International Review 54, 527-550.

Nummela, N., Saarenketo, S., Loane, S., 2016. The dynamics of failure in international new ventures: A case study of Finnish and Irish software companies. International Small Business Journal 34, 51-69. https://doi.org/10.1177/0266242614539363

Nummela, N., Saarenketo, S., Puumalainen, K., 2004. A global mindset - a prerequisite for successful internationalization? Canadian Journal of Administrative Sciences/Revue Canadienne des Sciences de l'Administration 21, 51-64.

O’Connor, A., Stam, E., Sussan, F., Audretsch, D.B., 2018. Entrepreneurial Ecosystems: The Foundations of Place-based Renewal, in: Entrepreneurial Ecosystems. Springer, pp. 121.

Oviatt, B.M., McDougall, P.P., 1994. Toward a theory of international new ventures. Journal of international business studies 25, 45-64.

Pauwels, C., Clarysse, B., Wright, M., Van Hove, J., 2016. Understanding a new generation incubation model: The accelerator. Technovation 50, 13-24.

Peiris, I.K., Akoorie, M.E.M., Sinha, P., 2012. International entrepreneurship: A critical analysis of studies in the past two decades and future directions for research. Journal of International Entrepreneurship 10, 279-324. https://doi.org/10.1007/s10843-012-0096-3

Podsakoff, P.M., MacKenzie, S.B., Lee, J.-Y., Podsakoff, N.P., 2003. Common method biases in behavioral research: A critical review of the literature and recommended remedies. Journal of applied psychology 88, 879 .

Rauch, A., Rijsdijk, S.A., 2013. The effects of general and specific human capital on long-term growth and failure of newly founded businesses. Entrepreneurship Theory and Practice 37, 923-941.

Renko, M., El Tarabishy, A., Carsrud, A.L., Brännback, M., 2015. Understanding and Measuring Entrepreneurial Leadership Style. Journal of Small Business Management 53, 5474. https://doi.org/10.1111/jsbm.12086

Rialp, A., Galván-Sánchez, I., García, M., 2012. An inquiry into born global firms' learning process: A case study of information technology-based SMEs. Handbook of research on born globals 71-95.

Sasi, V., Arenius, P., 2012. Chapter 6 Strategies for Circumventing Born Global Firms' Resource Scarcity Dilemma, in: New Technology-Based Firms in the New Millennium. Emerald Group Publishing Limited, pp. 71-85.

Saxenian, A., 1990. Regional networks and the resurgence of Silicon Valley. California Management Review 33, 89-112. 
Sergeevich, M.A., Alekseevna, M.A., 2015. Geographies of Cluster Internationalization: Interorganizational Linkages on the Baltica. International Journal of Econometrics and Financial Management 7.

Shane, S., Venkataraman, S., 2000. The Promise of Entrepreneurship as a Field of Research. Academy of Management Review 217-226. https://doi.org/10.5465/AMR.2000.2791611

Spigel, B., 2017. The relational organization of entrepreneurial ecosystems. Entrepreneurship Theory and Practice 41, 49-72.

Spigel, B., 2015. The Relational Organization of Entrepreneurial Ecosystems. Entrepreneurship Theory and Practice n/a-n/a. https://doi.org/10.1111/etap.12167

Spigel, B., Harrison, R., 2018. Toward a process theory of entrepreneurial ecosystems. Strategic Entrepreneurship Journal 12, 151-168.

Spilling, O.R., 1996. The Entrepreneurial System: On Entrepreneurship in the Context of a Mega-Event. Journal of Business Research 36, 91-103.

Stagars, M., 2015. Incubators and Accelerators, in: University Startups and Spin-Offs. Apress, pp. 131-136. https://doi.org/10.1007/978-1-4842-0623-2_13

Stam, E., 2015. Entrepreneurial Ecosystems and Regional Policy: A Sympathetic Critique. European Planning Studies 23, 1759-1769. https://doi.org/10.1080/09654313.2015.1061484

Stam, E., 2014. The Dutch Entrepreneurial Ecosystem (SSRN Scholarly Paper). Social Science Research Network, Rochester, NY.

Suddaby, R., Bruton, G.D., Si, S.X., 2015. Entrepreneurship through a qualitative lens: Insights on the construction and/or discovery of entrepreneurial opportunity. Journal of Business Venturing 30, 1-10.

Suresh, J., Ramraj, R., 2012. Entrepreneurial ecosystem: Case study on the influence of environmental factors on entrepreneurial success. European Journal of Business and Management 4, 95-101.

Talaia, M., Pisoni, A., Onetti, A., 2016. Factors influencing the fund raising process for innovative new ventures: an empirical study. Jrnl of Small Bus Ente Dev 23, 363-378. https://doi.org/10.1108/JSBED-07-2014-0111

Thomas, L.D.W., Sharapov, D., Autio, E., 2015. Linking Entrepreneurial and Innovation Ecosystems: The Case of Appcampus.

Van de Ven, A.H., 1993. The Development of an Infrastracture for Entrepreneurship. Journal of Business Venturing 8. https://doi.org/10.1016/0883-9026(93)90028-4

Velt, H., Torkkeli, L., Saarenketo, S., 2018a. Uncovering New Value Frontiers: The Role of the Entrepreneurial Ecosystem in Nurturing Born Globals. Int. J. Export Marketing 2.

Velt, H., Torkkeli, L., Saarenketo, S., 2018b. Entrepreneurial Ecosystem and Born Globals: The Estonian Startup Scene. Special Issue: Entrepreneurial Ecosystems.

Vissak, T., 2007. The emergence and success factors of fast internationalizers: four cases from Estonia. Journal of East-West Business 13, 11-33.

Weber, E.P., Khademian, A.M., 2008. Wicked Problems, Knowledge Challenges, and Collaborative Capacity Builders in Network Settings. Public Administration Review 68, 334349. https://doi.org/10.1111/j.1540-6210.2007.00866.x

Winton, A., Yerramilli, V., 2008. Entrepreneurial finance: Banks versus venture capital. Journal of Financial Economics 88, 51-79. https://doi.org/10.1016/j.jfineco.2007.05.004

Wong, A., Bhatia, M., Freeman, Z., 2009. Angel finance: the other venture capital. Strategic change 18, 221-230.

Wu, J., Si, S., Wu, X., 2016. Entrepreneurial Finance and Innovation: Informal Debt as an Empirical Case. Strategic Entrepreneurship Journal. 
Yukl, G., 2008. How leaders influence organizational effectiveness. The Leadership Quarterly 19, 708-722. https://doi.org/10.1016/j.leaqua.2008.09.008

Zander, I., McDougall-Covin, P., Rose, E.L., 2015. Born globals and international business: Evolution of a field of research. Journal of International Business Studies 46, 27-35.

Zhang, Y., Li, H., 2010. Innovation search of new ventures in a technology cluster: the role of ties with service intermediaries. Strategic Management Journal 31, 88-109.

Zhou, L., Wu, W., Luo, X., 2007. Internationalization and the performance of born-global SMEs: the mediating role of social networks. Journal of international business studies 38, 673-690.

Zoltán J., Audretsch, D.B., Lehmann, E.E., Licht, G., 2016. National systems of entrepreneurship. Small Business Economics 46, 527-535.

Zott, C., Huy, Q.N., 2007. How entrepreneurs use symbolic management to acquire resources. Administrative Science Quarterly 52, 70-105. 
Table 1. Results

\begin{tabular}{|c|c|c|c|c|c|c|c|c|c|c|c|c|c|}
\hline $\begin{array}{c}\text { Results } \\
\text { [Q1 \& Q2] }\end{array}$ & Cri & $\begin{array}{r}\text { icality } \\
\text { [Q1] }\end{array}$ & & $\begin{array}{l}\mathrm{Me} \\
{[\mathrm{Sc}:}\end{array}$ & $\begin{array}{l}\text { an Val } \\
\text { ale 0-1 }\end{array}$ & $\begin{array}{l}\text { ues } \\
00]\end{array}$ & $\begin{array}{c}\text { ANOVA } \\
\text { [Q2] }\end{array}$ & \begin{tabular}{|l|} 
Stages \\
{$\left[\begin{array}{lll}1 & \& & 2\end{array}\right]$}
\end{tabular} & $\begin{array}{c}\text { Stat. Sign. } \\
{[* * ; * ;-]}\end{array}$ & & $\begin{array}{r}\text { Mean D } \\
{[0} \\
\end{array}$ & 1] & \\
\hline Elements & St. 1. & St. 2 . & $\bar{\Delta}$ & St. 1. & St. 2. & $\bar{\Delta}$ & BG Characteristics & $\overline{\#}$ & Coeff. & $\overline{0}$ & 1 & $\overline{\text { Diff. }}$ & $\overline{\mathrm{Sd}}$ \\
\hline Entrepreneurial Talent & 1. & 1. & 0 & 85.83 & 84.75 & -1.08 & - & - & - & - & - & - & - \\
\hline Knowledge & 2. & 2. & 0 & 77.70 & 82.98 & 5.28 & $\begin{array}{l}\text { Age }[0=4 \rightarrow 6 ; 1=0 \rightarrow 3] \\
\text { Team Size }[0=1 \rightarrow 9 ; 1=10 \rightarrow \ldots] \\
\text { Revenue }[0=\text { pre-revenue; } 1=\text { revenue }] \\
\text { Firm Offer }[0=\text { product; } 1=\text { service }] \\
\# \text { of Markets }[0=5 \rightarrow 9 ; 1=10 \rightarrow \ldots]\end{array}$ & $\begin{array}{l}\text { St. } 1 . \\
\text { St. } 1 . \\
\text { St. } 2 \text {. } \\
\text { St. } 2 \text {. } \\
\text { St. } 2 \text {. }\end{array}$ & $\begin{array}{l}-0.207^{*} \\
0.208^{*} \\
-0.272^{*} \\
0.170^{*} \\
0.142 *\end{array}$ & $\begin{array}{l}82.64 \\
73.98 \\
88.84 \\
80.54 \\
81.17\end{array}$ & $\begin{array}{l}73.81 \\
82.91 \\
80.49 \\
85.30 \\
85.16\end{array}$ & $\begin{array}{l}-8.83 \\
8.93 \\
-8.35 \\
4.76 \\
3.99\end{array}$ & $\begin{array}{l}21.27 \\
21.27 \\
14.09 \\
14.09 \\
14.09\end{array}$ \\
\hline Informal Debt & 3. & 13. & -10 & 77.07 & 47.21 & -29.86 & $\begin{array}{l}\text { Age }[0=4 \rightarrow 6 ; \quad 1=0 \rightarrow 3] \\
\text { Ownership Origin }[0=\text { home; } 1=\text { foreign }]\end{array}$ & $\begin{array}{l}\text { St. } 1 . \\
\text { St. } 1 .\end{array}$ & $\begin{array}{l}0.292 * * \\
0.166 *\end{array}$ & $\begin{array}{l}69.68 \\
73.33\end{array}$ & $\begin{array}{l}82.89 \\
80.81\end{array}$ & $\begin{array}{c}13.21 \\
7.48\end{array}$ & $\begin{array}{l}22.60 \\
22.60\end{array}$ \\
\hline Leadership & 4. & 6. & -2 & 73.13 & 68.33 & -4.80 & Team Allocation [0= local; $1=$ global $]$ & St. 2 . & $-0.142 *$ & 71.33 & 64.87 & -6.46 & 22.79 \\
\hline Bootstrapping & 5. & 10. & -5 & 71.83 & 55.46 & -16.37 & - & - & - & - & - & - & - \\
\hline Networks & 6. & 4. & +2 & 68.46 & 76.24 & 7.78 & - & - & - & - & - & - & - \\
\hline Worker Talent & 7. & 3. & +4 & 64.70 & 81.67 & 16.97 & - & - & - & - & - & - & - \\
\hline Engagement Services & 8. & 12. & -5 & 64.31 & 52.89 & -11.42 & Revenue [0= pre-revenue; $1=$ revenue] & St. 1. & $0.230 *$ & 54.68 & 68.39 & 13.71 & 27.43 \\
\hline Intermediaries & 10. & 11. & -1 & 52.76 & 55.01 & 2.25 & - & - & - & - & - & - & - \\
\hline Networking Services & 11. & 9. & +2 & 45.00 & 56.67 & 11.67 & Ownership Origin $[0=$ home $; 1=$ foreign $]$ & St. 1. & $0.228^{*}$ & 39.00 & 51.00 & 12.00 & 26.45 \\
\hline Consultants & 12. & 8. & +4 & 44.11 & 61.50 & 17.39 & - & - & - & - & - & - & - \\
\hline Venture Capital & 13. & 5. & +8 & 41.62 & 73.29 & 31.67 & Ownership Origin $[0=$ home; $1=$ foreign $]$ & St. 1. & $0.220 *$ & 34.86 & 48.38 & 13.52 & 31.00 \\
\hline Crowdfunding & 14. & 15. & -1 & 35.87 & 42.02 & 6.15 & - & - & - & - & - & - & - \\
\hline Corp Venture Capital & 15. & 14. & +1 & 21.95 & 46.56 & 24.61 & $\begin{array}{l}\text { Revenue }[0=\text { pre-revenue; } 1=\text { revenue }] \\
\text { Ownership Origin }[0=\text { home; } 1=\text { foreign }]\end{array}$ & $\begin{array}{l}\text { St. } 1 . \\
\text { St. } 1 .\end{array}$ & $\begin{array}{l}-0.209^{*} \\
0.264^{*}\end{array}$ & $\begin{array}{l}29.52 \\
15.74\end{array}$ & $\begin{array}{l}18.75 \\
28.17\end{array}$ & $\begin{array}{r}-10.77 \\
12.43\end{array}$ & $\begin{array}{l}23.66 \\
23.66\end{array}$ \\
\hline Credit Institution & 16. & 16. & 0 & 19.35 & 31.62 & 12.27 & Internationalization $[0=1 \rightarrow 3 ; 1=0 \rightarrow 1]$ & St. 2 . & $-0.197 *$ & 37.78 & 26.77 & -11.01 & 27.88 \\
\hline
\end{tabular}

Below cut-off points $56.57 \quad 61.17$

${ }^{(* *)} \mathrm{p}<.01 ;(*) \mathrm{p}<.05 ;(-)$ no stat. sign. difference among BGs

Page 1 of $\mathbf{2 5}$ 